\title{
IDENTIFICATION OF TUDOR DOMAIN CONTAINING 7 PROTEIN AS A NOVEL PARTNER AND A SUBSTRATE FOR RIBOSOMAL PROTEIN S6 KINASES - S6K1 AND S6K2
}

\author{
Oleksandr SKOROKHOD ${ }^{1,3}$, Ganna PANASYUK ${ }^{1}$, Ivan NEMAZANYY, \\ Ivan GOUT $T^{1,2}$, Valeriy FILONENKO ${ }^{1,3}$ \\ ${ }^{1}$ Department of Cell Signalling, Institute of Molecular Biology and Genetics, \\ National Academy of Sciences of Ukraine, Kyiv; \\ ${ }^{2}$ Department of Structural and Molecular Biology, University College London, United Kingdom; \\ ${ }^{3}$ The State Key Laboratory of Molecular and Cellular Biology, Kyiv, Ukraine; \\ e-mail: filonenko@imbg.org.ua
}

\begin{abstract}
Ribosomal protein S6 kinases (S6Ks) are principal regulators of cell size, growth and metabolism. Signaling via the PI3K/mTOR pathway mediates the activation of S6Ks in response to various mitogenic stimuli, $n u-$ trients and stresses. To date, the regulation and cellular functions of S6Ks are not fully understood. Our aim was to investigate and characterize the interaction of S6Ks with the novel binding partner of S6Ks, Tudor domain containing 7 protein (TDRD7), which is a scaffold protein detected in complexes involved in the regulation of cytoskeleton dynamics, $m R N A$ transport and translation, non-coding piRNAs processing and transposons silencing. This interaction was initially detected in the yeast two-hybrid screening of HeLa cDNA library and further confirmed by pull-down and co-immunoprecipitation assays. In addition we demonstrated that TDRD7 can form a complex with other isoform of $S 6 K-S 6 K 2$. Notably, both isoforms of S6K were found to phosphorylate TDRD7 in vitro at multiple phosphorylation sites. Altogether, these findings demonstrate that TDRD7 is a novel substrate of S6Ks, suggesting the involvement of S6K signaling in the regulation of TDRD7 cellular functions.
\end{abstract}

Ke y words: S6K1, S6K2, TDRD7, Tudor domain, phosphorylation.

$\mathrm{R}$ ibosomal protein S6 kinases (S6Ks) belong to the AGC family of Ser/Thr kinases and are implicated in the regulation of cell size, growth and metabolism. Mammalian cells express two isoforms of the kinase, S6K1 and S6K2, which are encoded by different genes (RPS6KB1 and RPS6KB2, respectively) [1-5]. Both genes encode short and long splicing isoforms of S6Ks via the use of alternative translational start sites [1]. The predominant short $(70 \mathrm{kDa})$ isoform of S6K1 is localized mainly, but not exclusively, within the cytoplasm, while a nuclear localization sequence (NLS) found within the N-terminal (23 aa.) extension of long S6K1 isoform $(85 \mathrm{kDa})$ may target it to the nucleus $[1,2]$. Similarly, the long $(56 \mathrm{kDa})$ isoform of S6K2 differs from the short $(54 \mathrm{kDa})$ splicing version by the presence of the NLS $[3,4]$ located within the N-terminal (13 aa.) extension. At the same time, both S6K2 isoforms contain an additional NLS at the C-terminus, which determines their predominant nuclear localization in quiescent cells [5].

Deficiency of both S6Ks is associated with a profound decrease in cell viability [6]. The observed phenotype can be rescued by the expression of either S6K isoform. The activity of S6 kinases is regulated by phosphorylation/dephosphorylation events in response to various extracellular stimuli $[7,8]$. Treatment of cells with growth factors, cytokines and hormones leads to a rapid activation of S6Ks, while growth inhibitory agents, such as steroids and TGFß, suppress their activities. Signalling via the PI3K and mTOR pathways, induced by growth factors or nutrients respectively, are the key events in the activation process of S6Ks [9-11].

At present, more than twenty known substrates have been described for S6Ks, but only few of them have well defined functional consequences [12].

A number of S6K-binding partners have been implicated in regulating its kinase activity, including small GTPases Racl and cdc42, protein kinases PDK1 and PKC $\gamma$, protein phosphatases PP2A and PP1 and cytoskeletal protein neurabin $[8,12-14]$.

Here, we report the identification of a novel S6K1/2 binding partner,Tudor domain containing 7 protein (TDRD7), which is known as a scaffold protein with molecular weight of approximately $130 \mathrm{kDa}$. TDRD7 was originally identified as a binding partner of Ser/Thr PCTAIRE2 kinase [15]. Further investigations have led to the discove- 
ry of TDRD7 in a complex with ik3/Cables - cyclin-dependent kinase binding protein [16].

TDRD7 is localized on the periphery of mitochondria and together with other members of tudor-family (TDRD1/MTR-1, TDRD6) has been implicated in the formation of polar/germinal granules (nuage), which contain Dicer and microRNAs. These structures are involved in the microRNA pathway and the formation of a ribonucleoprotein complex in spermatids [15, 17-19].

Other research groups suggested the involvement of TDRD7 in the complex with TACC1-chTOG-Aurora kinase A, which controls mRNA fate in conjunction with microtubule organization and the maintenance of cell polarity [20].

TDRD7 contain several unique domains in its structure. In particular, there are three LOTUS domains at the $\mathrm{N}$ terminus, which are associated with small RNA pathways in the germline [21]. A distinctive feature of TDRD7 is the presence of Tudor domains (Tudor 1 (460-582aa), Tudor 2 (649-776aa) and Tudor 3 (909-1027aa)). It is a large conserved domain, initially described in proteins associated with nucleic acids [22, 23]. Recent studies demonstrated that Tudor domains are specialized in the recognition of methylated lysine or methylated arginine sites, and are involved in chromatin remodelling (through histones dimethylation and RNA processing) [22-24]. Moreover, Tudor domain-containg proteins were shown to have chaperone-like activity, especially in the process of macromolecular complex formation [18, 22, 24-27].

In this study, we describe for the first time regulatory complexes between ribosomal protein S6 kinases (S6K1 and S6K2) and TDRD7. Specific phosphorylation of TDRD7 by both isoforms of S6K has been demonstrated in vitro, but the functional consequence of the TDRD7-S6K1 and TDRD7-S6K2 association in mammalian cells remains to be investigated.

\section{Materials and Methods}

Production and purification of fusion proteins. Full-length coding sequence of TDRD7 and several cDNA fragments (F1 (1-290 aa); F2 (181-411 aa); F3 (381-620 aa); F5 (620-873 aa); F6 (8601098 aa) were amplified by PCR using specific oligonucleotides. Amplified cDNA fragments were purified and cloned into pET30a vector (Novagen) in frame with the $\mathrm{N}$-terminal and $\mathrm{C}$-terminal $6 \mathrm{His}-\mathrm{tags}$. The expression of $6 \mathrm{His}$-fusion recombinant proteins was performed in BL21 DE3 E. coli strain by induction with IPTG for $3 \mathrm{~h}$ at $30^{\circ} \mathrm{C}$. Recombinant His-TDRD7 fusion proteins were affinity purified on TALON resin (BD-Clon- tech, USA) from soluble fractions according to the manufacturer's recommendations. The qulity of purified fusion proteins was analysed by SDSPAGE.

EE-S6K1 and S6K2 proteins were purified from insect cells infected with recombinant S6K1 or S6K2 baculoviruses as previously described (14).

Reagents, antibodies and cell culture. Generation of anti-TDRD7 mAbs (specific to 181-411aa sequence), anti-S6K2 mAbs (2B) (specific to the $\mathrm{N}$-terminal region of S6K2) and anti-S6K1 polyclonal antibodies (specific to the $\mathrm{C}$-terminal region of S6K1) has been described previously [28-30]. Anti-His antibodies were purchased from Santa Cruz.

Human embryonic kidney cells HEK293 (obtained from ATCC) were maintained at $37^{\circ} \mathrm{C}$ and $5 \% \mathrm{CO}_{2}$ in Dulbecco's modified Eagle's medium (DMEM) supplemented with $10 \%$ fetal bovine serum (FBS; Life Technologies, Inc.), $50 \mathrm{U} / \mathrm{ml}$ penicillin and $50 \mu \mathrm{g} / \mathrm{ml}$ streptomycin.

TDRD7-S6K1 pull-down assay. $0.1 \mu \mathrm{g}$ of 6Histag TDRD7 fusion proteins were incubated with HisLink resine (Promega) for $1 \mathrm{~h}$ at $4{ }^{\circ} \mathrm{C}$ in lysis buffer (20 mM Tris- $\mathrm{HCl}$ (pH 7.5), $150 \mathrm{mM} \mathrm{NaCl}$, $1 \%$ Triton $\mathrm{X}-100,50 \mathrm{mM} \mathrm{NaF}, 5 \mathrm{mM}$ EDTA, and a mixture of protease inhibitors (Roche Molecular Diagnostics, Meylan, France). The beads were then washed three times and incubated at $4{ }^{\circ} \mathrm{C}$ for $3 \mathrm{~h}$ in the same buffer with $50 \mathrm{ng}$ of baculovirally produced EE-S6K1 protein obtained previously [31] (Panasyuk et al., 2006). Bound proteins were eluted by boiling in Laemmli sample buffer, resolved by SDS-PAGE, transferred to PVDF membrane and detected by immunoblotting with antiS6K1 polyclonal antibodies.

Immunoprecipitation. Supernatants of HEK 293 cells were prepared from total lysate and subjected to immunoprecipitation using appropriate antibodies and protein A-Sepharose beads (Amersham). Briefly, $1 \mu \mathrm{g}$ of mAbs in a total volume of $1 \mathrm{~mL}$ was incubated at $4{ }^{\circ} \mathrm{C}$ for $3 \mathrm{~h}$ with supernatnats, containing $500 \mu \mathrm{g}$ of total cellular protein and $15 \mu \mathrm{L}$ of $50 \%$ slurry of protein A-Sepharose preliminary washed with lysis buffer. Then, beads were washed three times with $1 \mathrm{~mL}$ of lysis buffer and boiled for 5 min in Laemmli sample buffer.

Immunoblolot analysis. Immune complexes or total cell lysates were separated by SDS-PAGE. Resolved proteins were electroblotted onto PVDF membrane and treated with appropriate antibodies as described previously [28]. The antigen-antibody complexes were detected using the ECL system (Millipore).

Far-Western blot analysis. EE-S6K1 $(0.4 \mu \mathrm{g} /$ line) was resolved by SDS-PAGE and transferred 
to PVDF membrane. The membrane was blocked with $2 \%$ BSA in TBS buffer $(50 \mathrm{mM}$ Tris- $\mathrm{HCl}$, $\mathrm{pH} 7.4,150 \mathrm{mM} \mathrm{NaCl}$ ) for $1 \mathrm{~h}$ at $4{ }^{\circ} \mathrm{C}$. Membrane strips were incubated in TBS buffer for $14 \mathrm{~h}$ at $4{ }^{\circ} \mathrm{C}$ with one of the recombinant TDRD7 peptides (F1, F2 or F6) diluted to $1 \mu \mathrm{g} / \mathrm{ml}$ or GST as a control. After washing three times with TBS-T (TBS buffer with 1\% Tween 20), strips were incubated with anti-His antibodies for $1 \mathrm{~h}$ at $4{ }^{\circ} \mathrm{C}$ in TBS buffer, washed three times with TBS-T and incubated with anti-rabbit secondary antibodies in $1: 5000$ dilution (Promega, USA) for $1 \mathrm{~h}$ at $4{ }^{\circ} \mathrm{C}$. Alternatively, strips were incubated with anti-S6K1 antibodies according to the procedure described above. Finally, the antigen-antibody complexes were detected using the ECL system (Millipore).

In vitro kinase assay. $0.1 \mu \mathrm{g}$ of recombinant EE-S6K1 or EE-S6K2 was incubated with $10 \mu \mathrm{Ci}$ $\left[\gamma-{ }^{32} \mathrm{P}\right]$ ATP and $0.2 \mu \mathrm{g}$ of purified TDRD7 proteins as substrates in $30 \mu \mathrm{l}$ of kinase assay buffer (10 mM MOPS, pH 7.2, $5 \mathrm{mM} \beta$-glycerophosphate, $0.5 \mathrm{mM}$ EGTA, $10 \mathrm{mM} \mathrm{MgCl}$ and $0.5 \mathrm{mM}$ DTT). GST protein (Abcam) was used as a negative control for S6Ks. We used myelin basic protein (MBP) from Millipore to test the activity of S6Ks, as it is commonly used as a substrate for determining the activity of protein kinases in vitro [32, 33].

The reactions were carried out at $30{ }^{\circ} \mathrm{C}$ for 1 hour and stopped by adding Laemmli sample buffer. Protein complexes were separated by SDSPAGE, and phosphorylation of substrates was visualized by autoradiography, using Agfa X-ray films.

\section{Results}

The yeast twohybrid screen of a HeLa cDNA library with S6K1 as a bait allowed us to identify a number of known and novel binding partners [34]. Among them, 17 cDNA clones contained fulllength coding sequence for TDRD7 protein. Notably, all cDNAs had 5' non-coding sequences of various lengths and therefore originated from different mRNAs. The interaction of wild type S6K1 with TDRD7 in yeast cells was also confirmed in mating assay [34]. In this study, we focused on examining the specificity of TDRD7/S6Ks interaction in vitro and in mammalian cells, and on testing TDRD7 as a substrate for S6K1 and 2.

S6K1 interacts with TDRD7 in vitro. To confirm the interaction between S6K1 and TDRD7, recombinant proteins were used in in vitro binding
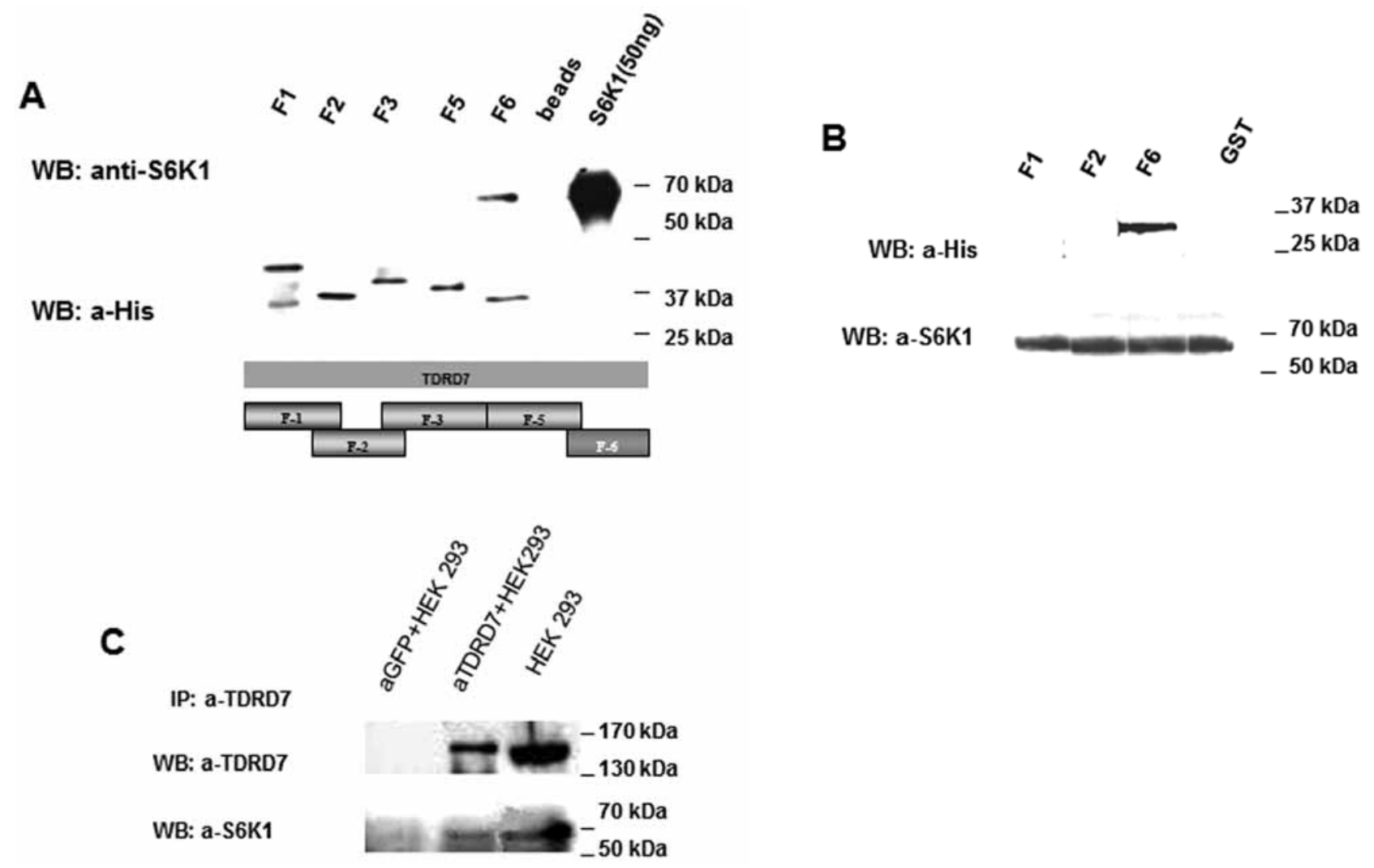

Fig. 1. In vitro and in vivo association between S6K1 and TDRD7. A - S6K1 interacts with C-terminal fragment of TDRD7(F6) in pull-down assay. $\boldsymbol{B}-S 6 K 1$ interacts with $C$-terminal fragment of TDRD7 in FarWestern blot. C-S6K1 is co-immunoprecipitated with TDRD7 in HEK293 cell lysate 
assays. The EE-tagged S6K1 was generated using baculovirus expression system and assessed for its capability to interact with a panel of His-TDRD7 fusion proteins bound to the HisLink resin (see Matherials and Methods). The specificity of interaction between His-TDRD7 proteins and S6K1 was analysed by immunobloting with antiS6K1 antibodies. As shown in Fig. 1A, specific interaction was only observed between EE-S6K1 and the F6 fusion protein, corresponding to the C-terminal region of TDRD7.

Furthermore, we confirmed the interaction between EE-S6K1 and the C-terminal region of TDRD7 by Far-Western blot analysis. As Fig. 1B shows, the C-terminal fragment of TDRD7 interacts specifically with EE-S6K1 and this interaction is possibly mediated via the Tudor domains.

TDRD7 forms a complex with S6K1 in vivo. The association of S6K1 with the C-terminal fragment of TDRD7 in a pull-down assay and Far-Western blot encouraged us to test the interaction between endogenous S6K1 and TDRD7 in HEK 293 cells. For this purpose, we analyzed TDRD7 complexes immunoprecipitated from HEK 293 cell lysate using anti-TDRD7 mAbs [28]. The presence of S6K1 in the immune complex was detected by specific anti-S6K1 antibodies. As shown in Fig. 1C, S6K1 forms specific complex with TDRD7 in HEK293 cells. In a control experiment, we coupled antiGFP mAbs to beads and probed them with cell lysates. No binding of endogenous S6K1 with antiGFP beads was detected in this analysis.

S6K2 interacts with TDRD7 in HEK293 cells. Our finding of the TDRD7/S6K1 complex in mammalian cells, prompted us to investigate whether TDRD7 has the potential to interact with the second S6K isoform, S6K2. Endogenous S6K2 was immunoprecipitated with anti-S6K2 mAbs (2B) specific to the $\mathrm{N}$-terminal regulatory region and the immune complexes probed in Western blotting with anti-TDRD7 mAbs. The data presented in Fig. 2 clearly indicate that TDRD7 is specifically co-immunoprecipitated from HEK293 cell lysate with S6K2.

Both S6K isoforms phosphorylate TDRD7 in vitro. To address functional consequences of the TDRD7-S6K1 and TDRD7-S6K2 interactions in mammalian cells, we examined whether S6K1 or/and S6K2 can phosphorylate TDRD7 in vitro. Initially we performed a bioinformatic analysis of TDRD7 amino acid sequence for the presence of potential S6K1 or S6K2 phosphorylation sites, using different online resources, including PhosphoNET (www.phosphonet.ca), HPRD (www.hprd. org), PSP (www.phosphosite.org), PPSP (http:// ppsp.biocuckoo.org) [32, 35-37].

Bioinformatic analysis revealed the presence of several potential phosphorylation sites for S6Ks in TDRD7. Notably, some of these phosphorylation motifs were located in F1, F2, F5 and F6 TDRD7 constructs (Fig. 3A). In total, the analysis

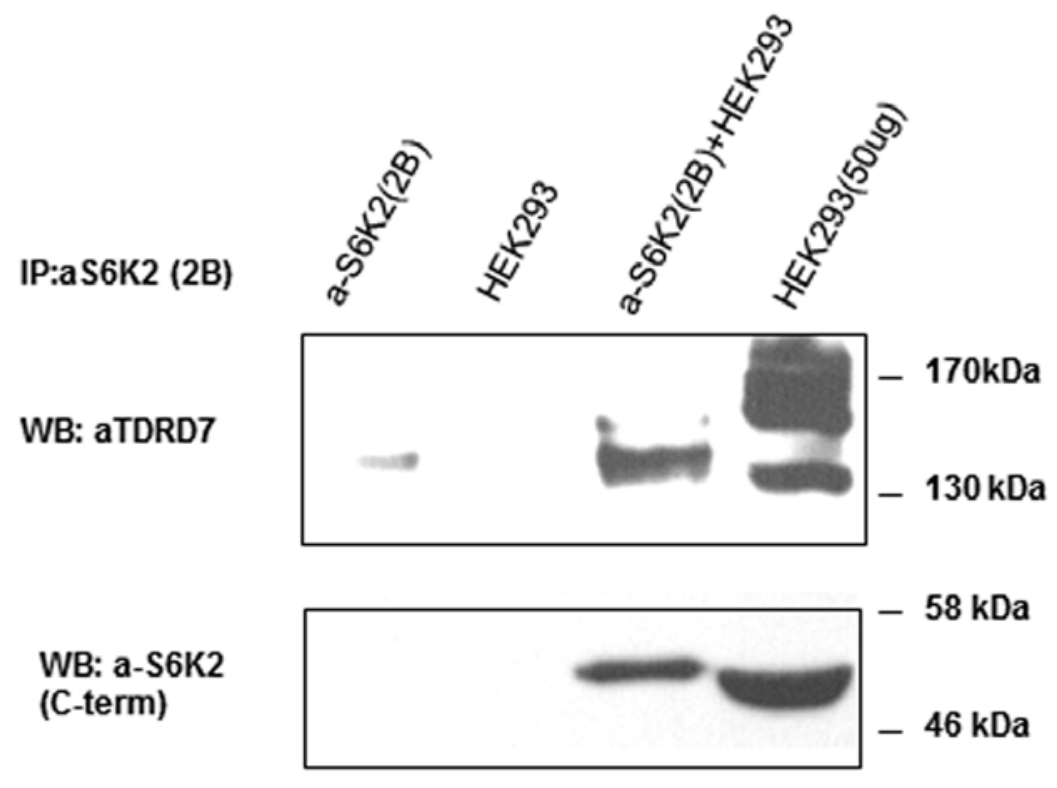

Fig. 2. In vivo association between S6K2 and TDRD7. S6K2 was immunoprecipitated from cell lysates with anti-S6K2 (2B) mAbs. The immune complexes were eluted by boiling in Laemmli sample buffer, resolved by SDS-PAGE and analysed by anti-TDRD $7 \mathrm{mAbs}$ and anti-S6K2 C-terminal polyclonal antibodies. Beads incubated with anti-S6K2 (2B) or HEK 293 lyzate along were used to test the specificity of co-immunoprecipitation 
A

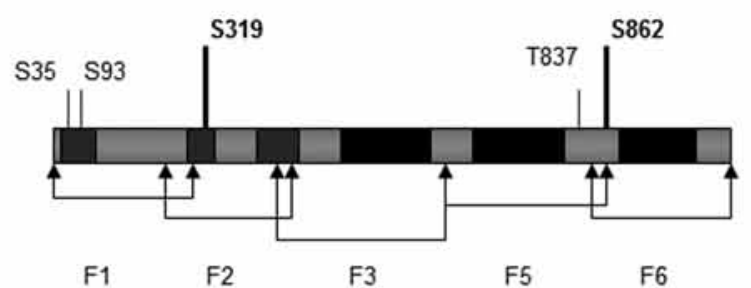

C

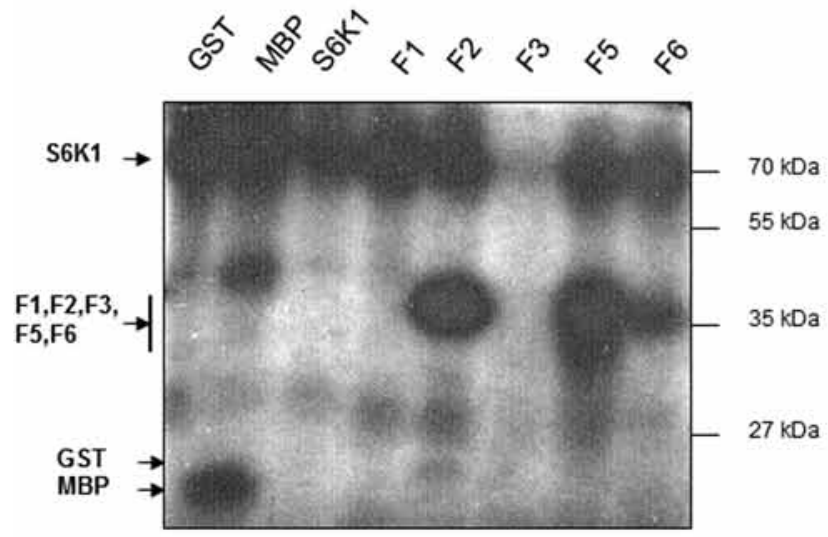

B

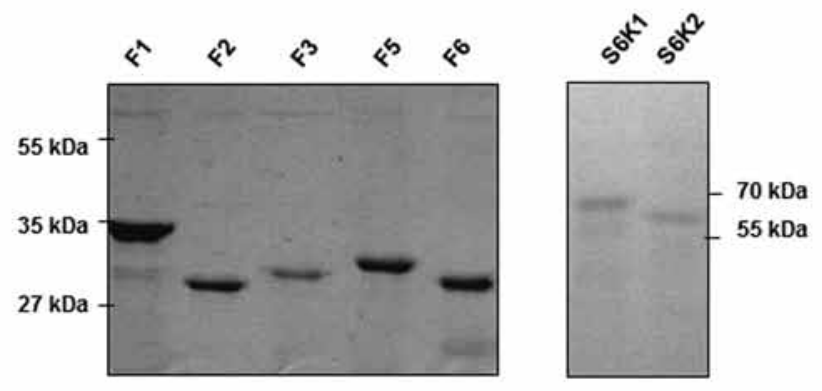

D

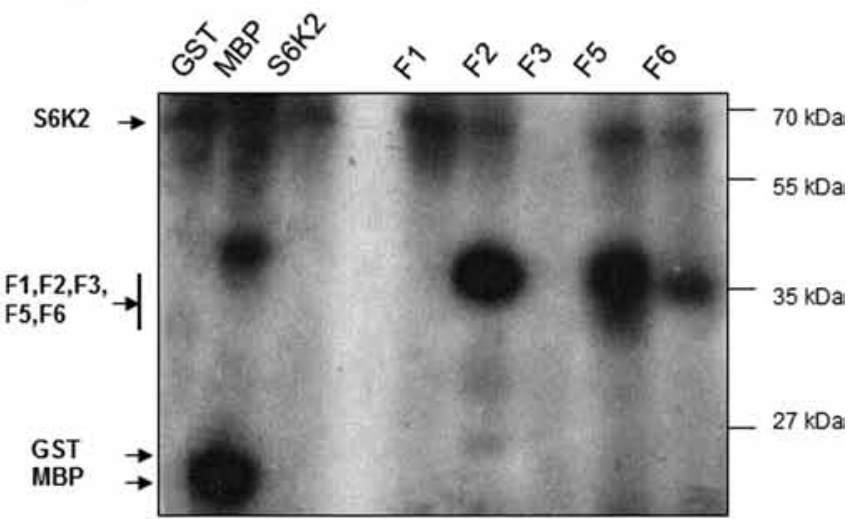

Fig. 3. S6K1 and S6K2 specifically phosphorylates TDRD7 fragments in vitro. $\boldsymbol{A}$ - Bioinformatical analysis of TDRD7 structure, with an indication of potential S6K phosphorylation sites. $\boldsymbol{B}-S D S-P A G E$ analysis of purified recombinanr peptides (0,2 $\mu \mathrm{g} /$ lane) of TDRD7 (left panel) and recombinant S6K1 (1 $\mu \mathrm{g} /$ lane) and S6K2 (1 $\mathrm{g} /$ /lane) (right panel) used for in vitro kinase reaction. $C$ - In vitro phosphorylation of TDRD7 fragments by S6K1. D - In vitro phosphorylation of TDRD7 fragments by S6K2

revealed five potential sites for S6 kinase phosphorylation (according to the highest predicted score) within the TDRD7 sequence. Two of them (Ser35 and Ser92) are located within the F1 fragment, one (Ser319) in F2, two (Thr837 and Ser862) in F5 fragment and one (Ser862) in the C-terminal F6 fragment. The highest probability was for Ser319 and Ser862, mapped to peptides F2 and F6, respectively (Fig. 3A).

To verify the bioinformatic prediction, we performed an in vitro S6K1 and S6K2 kinase assay using as a substrate different His-TDRD7 fusion proteins. The data presented in Fig. 3C clearly indicate that both S6K1 and S6K2 readily phosphorylate F2, F5 and F6 proteins. No phosphorylation of F1 and F3 was detected in several independent experiments. High level of S6K1 and S6K2 autophosphorylation in this assay indicated the use of highly active recombinant S6Ks.

\section{Discussion}

In summary, our results demonstrate for the first time that both S6K1 and S6K2 directly interact with TDRD7 protein in vitro and in mammalian cells. In addition, bioinformatic analysis revealed the existence of several S6K1 and S6K2 phosphorylation sites in TDRD7 (presumably Ser319, Thr837 and Ser862). Phosphoryaltion of TDRD7 by recombinant S6K1/2 was confirmed in in vitro kinase assay.

The functional consequence of TDRD7-S6K1 and TDRD7-S6K2 interactions in cells is intriguing and remains to be answered. Although the role of TDRD7 in cell is still insufficiently studied, nevertheless this protein is of a great interest due to its presence in complexes that are involved in the regulation of gene silencing, small non-coding mRNA processing, mRNA transport and translation, microtubule dynamics and centrosomal or- 
ganization $[13,15]$. The above data allow us to speculate that S6Ks may influence TDRD7 adaptor functions through site-specific phosphorylations, which can drive the formation of regulatory complexes, consisiting of signalling proteins and RNAs.

Subcellular localization of TDRD7/S6K1 and TDRD7/S6K 2 complexes is another interesting question which remains to be examined. It has been previously reported that TDRD7 is localized to P-bodies and so-called germinal granules (for germ cells), which are mainly detected in close proximity to mitochondrial and nuclear membranes. Notably, TDRD7 was also detected in cytoplasmic structures of unknown functions [18]. It was speculated that these cytosolic structures may contain the TACC-chTOG-PCTAIRE-TDRD7 complexes, involved in mRNA transport and the regulation of translation [20]. We can not exclude that the phosphorylation of TDRD7 by S6K1 or/ and S6K2 may influence TDRD7 association with other proteins/RNAs and its subcellular localization. Taking into account that S6K1 and S6K2 possess NLS-motifs, the interaction with TDRD7 also may be important for the regulation of S6K1 and/or S6K2 nucleocytoplasmic shuttling.

Therefore, further investigation of theTDRD7S6K1 and TDRD7-S6K2 functional complexes in cells could shed light on many hidden aspects of S6Ks signalling within the cell.

This work was supported by the National Academy of Sciences of Ukraine, the State Fund of Fundamental Research of Ukraine (grant №F46/457-2011) and FEBS summer fellowship.

\section{Acknowledgments}

The authors thank Oksana Breus for her assistance on this project.

\section{ВИВЧЕННЯ TUDOR- ДОМЕНВМІСНОГО 7 ПРОТЕЇНУ ЯК НОВОГО ПАРТНЕРА ТА СУБСТРАТУ КІНАЗ РИБОСОМНОГО ПРОТЕЇНУ S6 - S6K1 I S6K2}

О. Скороход ${ }^{1,3}$, Г. Панасюк', I. Немазаний ${ }^{1}$, I. Гут ${ }^{1,2}$, В. Філоненко ${ }^{1,3}$

${ }^{1}$ Інститут молекулярної біології і генетики НАН України, Київ;

${ }^{2}$ Університетський коледж

Лондона, Велика Британія;

З्Державна ключова лабораторія молекулярної і клітинної біології, Київ, Україна

Кінази рибосомного протеїну S6 (S6K) $€$ одними 3 головних регуляторів розміру клітин, їхнього росту та метаболізму. РІ3К/
mTOR-залежний сигнальний шлях координує регуляцію S6K у відповідь на різні мітогенні стимули, поживні речовини та стрес. Однак регуляція та клітинні функції S6K на сьогодні остаточно нез'ясовано. Метою наших досліджень було дослідити та охарактеризувати взаємодію S6K та нового протеїнупартнера Tudor-доменвмісного 7 протеїну (TDRD7), що є адаптерним протеїном і який виявлено в комплексах, залучених до регуляції реорганізації цитоскелета, транспорту та трансляції мРНК, процесингу некодуючих ріРНК та активності транспозонів. Попередньо виявлену взаємодію між S6K1 та TDRD7 у двогібридній системі дріжджів під час скринування кДНК бібліотеки клітин HeLa було підтверджено реакцією зв'язування in vitro та методом ко-імунопреципітації. Крім того встановлено, що TDRD7 здатен формувати комплекс з іншою високогомологічною ізоформою S6K - S6K2, і що обидві кінази здатні фосфорилювати TDRD7 in vitro за декількома сайтами. Одержані результати свідчать, що TDRD7 $€$ новим субстратом для S6K-кіназ, і вказують на залучення S6K-залежного сигналювання до регуляції клітинних функцій TDRD7.

Кл ючов і слова: S6K1, S6K2, TDRD7, Tudor-домен, фосфорилювання.

\section{ИЗУЧЕНИЕ TUDOR- ДОМЕНСОДЕРЖАЩЕГО 7 ПРОТЕИНА КАК НОВОГО ПАРТНЕРА И СУБСТРАТА КИНАЗ РИБОСОМНОГО ПРОТЕИНА S6 - S6K1 И S6K2}

А. Скороход И. Гут ${ }^{1,2}$, В. Филоненко ${ }^{1,3}$

\author{
${ }^{1}$ Институт молекулярной биологии \\ и генетики НАН Украины, Киев; \\ ${ }^{2}$ Университетский колледж \\ Лондона, Великобритания; \\ ${ }^{3}$ Государственная ключевая \\ лаборатория молекулярной и клеточной \\ биологии, Киев, Украина
}

Киназы рибосомного протеина S6 (S6K) являются одними из главных регуляторов клеточного размера, роста та метаболизма. РІ3K/ mTOR-зависимый сигнальный путь координирует регуляцию S6K в ответ на разные митогенные стимулы, питательные вещества и стресс. Однако регуляция и клеточные функции S6K до настоящего времени окончательно не определены. Целью наших исследований было изучить и охарактеризовать взаимодействие S6K и нового протеина-партнера киназ, 
Tudor-доменсодержащего 7 протеина, который является адаптерным протеином и находится в комплексах вовлеченных в регуляцию реорганизации цитоскелета, транспорт и трансляцию мРНК, процессинга некодирующих ріРНК и активность транспозонов. Предварительно обнаруженное взаимодействие между S6K1 и TDRD7 в двогибридной системе дрожжей при скринировании кДНК библиотеки клеток HeLa было подтверждено реакцией связывания in vitro и методом ко-иммунопреципитации. Кроме того, установлено, что TDRD7 способен формировать комплекс с другой высокогомологичной изоформой S6K - S6K2 и что обе киназы S5K способны фосфорилировать TDRD7 in vitro по нескольким сайтам. Полученные peзультаты свидетельствуют о том, что TDRD7 является новым субстратом для S6K-киназ, что указывает на участие S6K-зависимого сигналинга в регуляции клеточных функций TDRD7.

К л ю че вы е слова: $\mathrm{S} 6 \mathrm{~K} 1, \quad \mathrm{~S} 6 \mathrm{~K} 2$, TDRD7, Tudor-домен, фосфорилирование.

1. Grove J., Banerjee P., Balasubramanyam A. et al. // Mol. Cell Biol. - 1991. - 11. - P. 55415550.

2. Saitoh M., Dijke P., Miyazono K., Ichijo H. // Biochem. Biophys. Res. Commun. - 1998. 253. - P. 470-476.

3. Jeno P., Ballou L., Novak-Hofer I., Thomas G. // Proc. Natl. Acad. Sci. USA. - 1988. - 85. P. 406-410.

4. Gout I., Minami T., Hara K. et al. // J. Biol. Chem. - 1998. - 273. - P. 30061-30064.

5. Koh H., Jee K., Lee B. et al. // Oncogene. 1999. - 18. - P. 5115-5119.

6. Pende M., Um S., Mieulet V. et al. // Mol. Cell. Biol. - 2004. - 24. - P. 3112-3124.

7. Shima H., Pende M., Chen Y. et al. // EMBO J. - 1998. - 17. - P. 6649-6659.

8. Andres J., Johansen J., Maller J. // J. Biol. Chem. - 1987. - 262. - P. 14389-14393.

9. Avruch J., Belham C., Weng Q. et al. // Prog. Mol. Subcell. Biol. - 2001. - 26. - P. 115-154.

10. Ruvinsky I., Meyuhas O. // Trends. Biochem. Sci. - 2006. - 31. - P. 342-348.

11. Giraud J., Leshan R., Lee Y., White M. // J. Biol. Chem. - 2004. - 279. - P. 3447-3454.

12. Fenton T., Gout I. // Int. J. Biochem. Cell. Biol. - 2011. - 43. - P. 47-59.

13. Thomas G. // Biol. Res. - 2002. - 35. P. 305-313.

14. Valovka T., Verdier F., Cramer R. et al. // Mol. Cell Biol. - 2003. - 23. - P. 852-863.
15. Hirose T., Kawabuchi M., Tamaru T. et al. // Eur. J. Biochem - 2000. - 267. - P. 2113-2121.

16. Yamochi T., Nishimoto I., Tsukasa O., Matsuoka M. // Biochem. Biophys. Res. Commun. - 2001. - 286. - P. 1045-1050.

17. Chuma S., Hosokawa M., Kitamura K. et al. // Proc. Natl. Acad. Sci. USA. - 2006. - 103. P. 15894-15899.

18. Hosokawa M., Shoji M., Kitamura K. et al. // Dev. Biol. - 2007. - 301. - P. 38-52.

19. Kotaja N., Bhattacharyya S., Jaskiewicz L. et al. // Proc. Natl. Acad. Sci. USA. - 2006. 103. - P. 2647-2652.

20. Conte N., Delaval B., Ginestier C. et al. // Oncogene. - 2003. - 22. - P. 8102-8116.

21. Callebaut I., Mornon J. P. // Bioinformatics. 2010. - 26. - P. 1140-1144.

22. Selenko P., Sprangers R., Stier G. et al. // Nat. Struct. Biol. - 2001. - 8. - P. 27-31.

23. Amikura R., Hanyu K., Kashikawa M., Kobayashi S. // Mech. Dev. - 2001. - 107. P. 97-104.

24. Huyen Y., Zgheib O. // Nature. - 2004. 432. - P. 406-411.

25. Jin J., Xie X., Chen C. et al. // Sci. Signal. 2009. - 2. - P. 1-19.

26. Cote J., Richard S. // J. Biol. Chem. - 2005. 280. - P. 28476-28483.

27. Thomson T., Lasko P. // Cell Res. - 2005. 15. - P. 281-291.

28. Skorokhod O., Nemazanyy I., Breus O. et al. // Hybridoma (Larchmt). - 2008. - 27. P. 211-216.

29. Valovka T., Filonenko V., Velykyi M. et al. // Ukr. Biokhim. Zh. - 2000. - 72. - P. 31-37.

30. Savinska L., Skorokhod O., Klipa O. et al. // Hybridoma (Larchmt). - 2012. - 31. P. 289-294.

31. Panasyuk G., Nemazanyy I., Zhyvoloup A. et al. // J. Biol. Chem. - 2006. - 281. - P. 3118831201.

32. PhosphoNET: Human phosphosite knowledge base (PhosphoNET ID IPI00478741)

33. Chevalier D., Allen B. G. // Protein Expr. Purif. - 2000. - 18. - P. 229-234.

34. Panasyuk G., Nemzanyy I., Zhyvoloup A. et al. // Biopolym. Cell. - 2005. - 21. - P. 54075412.

35. HPRD: Human protein reference database (HPRD ID 11626).

36. PPSP: Prediction of PK-Specific Phosphorylation Site.

37. PSP: PhosphoSitePlus (PhosphoSitePlus ID Q8NHU6). 